\title{
DIVERSIFIKASI PENGOLAHAN IKAN NILA DI KECAMATAN LINGSAR, KABUPATEN LOMBOK BARAT, PROVINSI NUSA TENGGARA BARAT
}

\author{
oleh: \\ Juni Triastuti ${ }^{1}$, Adriana Monica Sahidu², Dwi Yuli Pujiastuti ${ }^{3}$ \\ 1,2,3 Departemen Kelautan, Program Studi Teknologi Hasil Perikanan, Fakultas Perikanan dan \\ Kelautan, Universitas Airlangga, Surabaya 60115 Indonesia \\ juni.triastuti@fpk.unair.ac.id
}

\begin{abstract}
Abstrak
Kecamatan Lingsar, Kabupaten Lombok Barat, Provinsi Nusa Tenggara Barat merupakan sentra perikanan tawar terutama ikan Nila, Lele dan Mas. Desa Sigerongan dan Saribaye, merupakan sentra perikanan tawar yang cukup maju di Kabupaten Lombok Barat dan karena hal tersebut maka lokasi kegiatan Pengabdian kepada Masyarakat dilakukan di Kelompok Pembudidaya Telaga Biru yang berlokasi di Desa Sigerongan dan Padegirang di Desa Saribaye. Pada hari besar keagamaan, produksi ikan cenderung meningkat karena pembudidaya ikan menaikkan jumlah ikan yang dipelihara untuk memenuhi kebutuhan masyarakat. Peningkatan produksi ikan yang melebihi permintaan masyarakat menyebabkan harga ikan menjadi murah. Salah satu upaya untuk mengatasi masalah tersebut adalah dengan memanfaatkan sekaligus meningkatkan nilai jual produksi ikan Nila melalui diversifikasi pengolahan ikan Nila menjadi berbagai produk olahan yang mudah diproduksi dan diminati masyarakat sehingga meningkatkan pendapatan masyarakat di kedua Desa. Program Pengabdian kepada Masyarakat dilaksanakan pada tanggal 13 dan 14 Juli 2018 dilanjutkan dengan evaluasi dan monitoring pada tanggal 25 dan 26 Oktober 2018. Kegiatan dijalankan melalui proses sosialisasi, pelatihan pembuatan nugget dan mie berbasis ikan Nila, pendampingan dan evaluasi kepada 30 orang pembudidaya meliputi istri dan anak pembudidaya sebagai sasaran antara, selain anggota Pemberdayaan Kesejahteraan Keluarga kedua desa tersebut. Pengujian organoleptik secara hedonik juga dilakukan untuk mengetahui tingkat kesukaan terhadap produk olahan ikan nila yang telah diproduksi. Hasil kegiatan menunjukkan bahwa setelah dilakukan penyuluhan tingkat pengetahuan dan keterampilan masyarakat terhadap produk olahan berbasis ikan Nila di dua Desa meningkat serta rata-rata nilai uji hedonik adalah menyukai produk nugget ikan Nila.
\end{abstract}

Kata kunci: diversifikasi, pengolahan, nila, nugget, mie

Abstract

Tilapia, catfish and goldfish are superior commodities in District of Lingsar, West Lombok Regency, West Nusa Tenggara Province. Sigerongan and Saribaye are two villages with fairly advanced freshwater center in West Lombok Regency. Therefore, the community service activities was carried out in the Telaga Biru Cultivators Group located in Sigerongan and Padegirang in Saribaye Village. On the ceremonial days, fish production was increasing due to the farmers increase the amount of fish. Increasing of the fish population made the value of fish was decreased. One effort to overcome this problem is to increase production for a variety of products that can produce better and easier products. The Community Service Program was carried out on 13 to 14 July, 2018 followed by evaluation and monitoring on 25 to 26 October, 2018. The activity was carried out through a socialization process, training on making nuggets and noodles based on tilapia, mentoring and evaluating 30 cultivators including the cultivator's wife and children as intermediate targets, in addition to members of the Family Welfare Empowerment of the two villages. Hedonic organoleptic testing was also carried out to determine the level of preference for tilapia processed products that have been produced. The results of the activity showed that after counseling, the level of knowledge and skills of the community towards tilapia-based processed products in two villages increased and the average hedonic test value was liking tilapia nuggets products.

Keywords: diversification, processing, tilapia, nugget, noodle

\section{PENDAHULUAN}

Indonesia merupakan negara dengan lahan perikanan yang cukup besar yang diusahakan di perairan tawar maupun laut. Salah satu wilayah di Indonesia yang berpotensi untuk mengembangkan budidaya ikan air tawar khususnya budidaya ikan dengan sistem air deras adalah Kabupaten Lombok Barat. Kabupaten Lombok Barat memiliki beberapa kecamatan yang 
berpotensi dalam pengembangan budidaya ikan air tawar, yaitu Kecamatan Narmada, Lingsar, Gunungsari, Kuripan dan Kediri.

Kecamatan Lingsar merupakan salah satu wilayah yang diidentikkan dengan kegiatan penerapan budidaya ikan menggunakan metode air deras secara intensif (DKP Lombok Barat, 2016). Menurut data lombokbaratkab.go.id (2018), Kecamatan Lingsar adalah daerah pegunungan yang memiliki sumber air sungai yang mengalir ke wilayah bagian tengah dan bermuara di pantai barat. Sumber air sungai yang terus mengalir merupakan potensi yang sangat luar biasa untuk dimanfaatkan dalam usaha perikanan khususnya budidaya. Letak geografis Kecamatan Lingsar merupakan faktor utama terbentuknya desa budidaya ikan tersebut. Mayoritas penduduk Kecamatan Lingsar adalah pembudidaya ikan baik untuk pemenuhan permintaan benih maupun ukuran konsumsi masyarakat di Kabupaten Lombok Barat. Terdapat dua desa yang cukup maju, yaitu Desa Saribaye dan Sigerongan. Pembudidaya ikan air tawar di Desa Saribaye cukup banyak, salah satunya adalah Kelompok Pembudidaya Pade Girang dan untuk Desa Sigerongan terdapat Kelompok Pembudidaya Ikan Telaga Biru. Kedua kelompok tersebut membudidayakan beberapa jenis ikan, yaitu nila, lele, patin dan mas, dimana ikan nila menjadi unggulan karena permintaan konsumen yang cukup tinggi.

Produksi ikan nila dari kedua desa tersebut cukup tinggi yang dipasok dari 2 hingga 3 kali siklus produksi dalam setahun dengan jumlah produksi sebesar kurang lebih 2,5 ton tiap siklus. Tingginya produksi tersebut tidak diikuti dengan nilai jual produksi dalam setahunnya. Setiap tahun, nilai jual produksi ikan nila selalu mengalami peningkatan dan penurunan harga. Hasil survei yang dilakukan menunjukkan bahwa penurunan nilai jual ikan nila sangat besar, hal ini terjadi saat peningkatan kebutuhan konsumen sebesar Rp. 28.000,00 - 30.000,00 dan akan menurun pada saat produksi melimpah sebesar Rp. 20.000,00 - 22.000,00 sedangkan harga normal adalah sebesar Rp. 22.500,00 - 25.000,00.

Hingga saat ini belum ada upaya yang dilakukan oleh pembudidaya maupun instansi yang terkait untuk meningkatkan nilai jual ikan nila pada saat terjadi penurunan harga. Salah satu usaha yang dapat dilakukan adalah memberikan solusi untuk memanfaatkan ikan ukuran konsumsi yang menurun harganya untuk dijadikan produk unggulan olahan hasil perikanan yang memiliki nilai ekonomi yang tinggi. Selain itu, produk olahan ikan dapat diproduksi dalam jumlah yang besar dan memiliki daya simpan lebih lama dibandingakan dengan produksi ikan segar. Hal ini memungkinkan untuk dilakukan pemasaran hasil olahan produk perikanan di daerah yang lebih luas. Menurut Suparmin dkk. (2013), pemasaran merupakan salah satu subsistem yang kompleks dan penting dalam agribisnis karena adanya perbedaan yang cukup mencolok antara produksi dan konsumsi, kegiatan pemasaran akan sangat berpengaruh terhadap pendapatan petani karena terkait langsung dengan tingkat harga yang diterima petani.

Kelompok Pembudidaya Ikan Pade Girang merupakan salah satu kelompok pembudidaya ikan di Desa Saribaye Kecamatan Lingsar yang fokus dalam usaha pembesaran ikan untuk konsumsi. Kelompok tersebut diketuai oleh Bapak Fauzi yang beranggotakan 17 orang. Kelompok Pembudidaya Ikan Telaga Biru Desa Sigerongan diketuai oleh Bapak Muzakir dengan anggota sebanyak 10 orang.

Kedua kelompok tersebut membudidayakan beberapa jenis ikan tawar khususnya ikan nila dengan harga jual yang cukup tinggi karena permintaan ikan nila ukuran konsumsi (ukuran 3-4 ekor per kilogram) cukup tinggi pula, yaitu sebesar Rp. $22.500,00$ - 25.000,00. Harga jual tersebut akan lebih tinggi lagi pada saat peringatan dan bulan keagamaan serta tahun baru, yaitu sebesar Rp. 28.000,00 - 30.000,00 dan akan turun hingga Rp.20.000,00 - 22.000,00 pada saat produksi melimpah. Untuk menyiasati turunnya harga jual ikan pada saat produksi berlimpah tersebut maka para pembudidaya akan memelihara ikan lebih lanjut hingga ukuran 2 ekor per kilogram untuk memenuhi permintaan usaha pemancingan.

Pemeliharaan ikan lebih lanjut akan berpotensi meningkatkan biaya produksi karena penggunaan pakan yang bertambah. Hal tersebut dapat menurunkan keuntungan yang diperoleh pembudidaya ikan karena harga jual ikan tidak dapat ditingkatkan lagi. Selain itu, bila ukuran ikan terlalu besar akan menurunkan minat beli untuk konsumsi maupun usaha pemancingan. Tingginya produksi ikan dengan ukuran yang melebihi permintaan konsumen dapat dijadikan sebagai indukan tetapi hal tersebut tidak 
dapat dilakukan pada semua ikan yang diproduksi. Hal ini karena banyaknya jumlah calon induk yang tersedia dan adanya syarat untuk menjadi induk yang tidak memungkinkan semua ikan yang diproduksi menjadi calon induk.

Hingga saat ini belum ada solusi yang ditawarkan dan diberikan kepada para pembudidaya ikan di Desa Saribaye dan Sigerongan Kecamatan Lingsar sehingga potensi besar budidaya ikan di kedua desa tersebut belum dimanfaatkan secara optimal. Perlu kiranya dilakukan intervensi dalam peningkatan dan optimalisasi produksi ikan di Desa Saribaye dan Sigerongan melalui kedua mitra yang terpilih dengan cara memberikan penyuluhan diversifikasi olahan ikan nila. Untuk itu, tujuan kegiatan Pengabdian kepada Masyarakat yang dilakukan adalah meningkatkan pengetahuan, keterampilan, kemampuan anggota keluarga pembudidaya ikan dan mendayagunakan potensi produksi ikan nila menjadi suatu diversifikasi produk yang diminati masyarakat serta meningkatkan perekonomian keluarga.

\section{METODE}

Pelaksanaan kegiatan diikuti oleh anggota keluarga kelompok pembudidaya ikan Telaga Biru (Desa Sigerongan) dan Padegirang (Desa Saribaye) sebagai sasaran antara dan masyarakat ke dua desa sebagai sasaran utama. Hal ini perlu dilakukan karena menjadi hal yang lazim di dalam masyarakat pedesaan, contoh keberhasilan akan menjadi role model dalam transfer teknologi. Dengan demikian, tujuan kegiatan Pengabdian kepada Masyarakat dapat tercapai dan keberlanjutannya dapat diharapkan.

Pelaksanaan kegiatan menggunakan metode terstruktur sesuai dengan tahapan yang tersaii pada Gambar 1.

\section{Gambar 1. Metode Pelaksanaan Kegiatan Pengabdian Kepada Masyarakat}

Pelaksanaan kegiatan yang dilakukan dalam program ini, meliputi: 1. Pendidikan / Penyuluhan melalui tatap muka dan diskusi dua arah tentang materi: a) pemanfaatan potensi dan bahan baku ikan nila, b) pengolahan ikan nila dan diversifikasi produk olahan berbahan dasar bahan baku ikan nila yang mudah, murah dan bernilai gizi. 2 . Pelatihan dan peningkatan keterampilan diversifikasi produk olahan dari bahan baku ikan nila pada kelompok mitra. 3. Praktek langsung dan bimbingan teknis pada kelompok mitra.

Kegiatan dilaksanakan di dua desa yaitu Desa Sigerongan dan Saribaye, Kecamatan Lingsar, Kabupaten Lombok Barat Nusa Tenggara Barat pada tanggal 13 dan 14 Juli 2018. Evaluasi dilakukan pada tanggal 25 dan 26 Oktober 2018. Dalam pelaksanaan evaluasi, masyarakat diberikan pengetahuan tentang pengujian organoleptik dengan menggunakan uji hedonik berdasarkan tingkat kesukaan. Panelis diminta tanggapan pribadinya tentang kesukaan atau ketidaksukaan terhadap produk yang disajikan. Skala hedonik dapat direntangkan atau diciutkan menurut rentangan skala yang dikehendaki. Pada evaluasi ini, panelis diminta untuk menilai kesukaan terhadap parameter kenampakan, bau, rasa dan tekstur. Pada awal dan akhir kegiatan dilakukan pengambilan data tentang pengetahuan dan keterampilan peserta terhadap jenis produk olahan berbahan dasar ikan dengan menggunakan kuisioner. Data yang diperoleh kemudian diolah dan dianalisa menggunakan metode deskriptif.

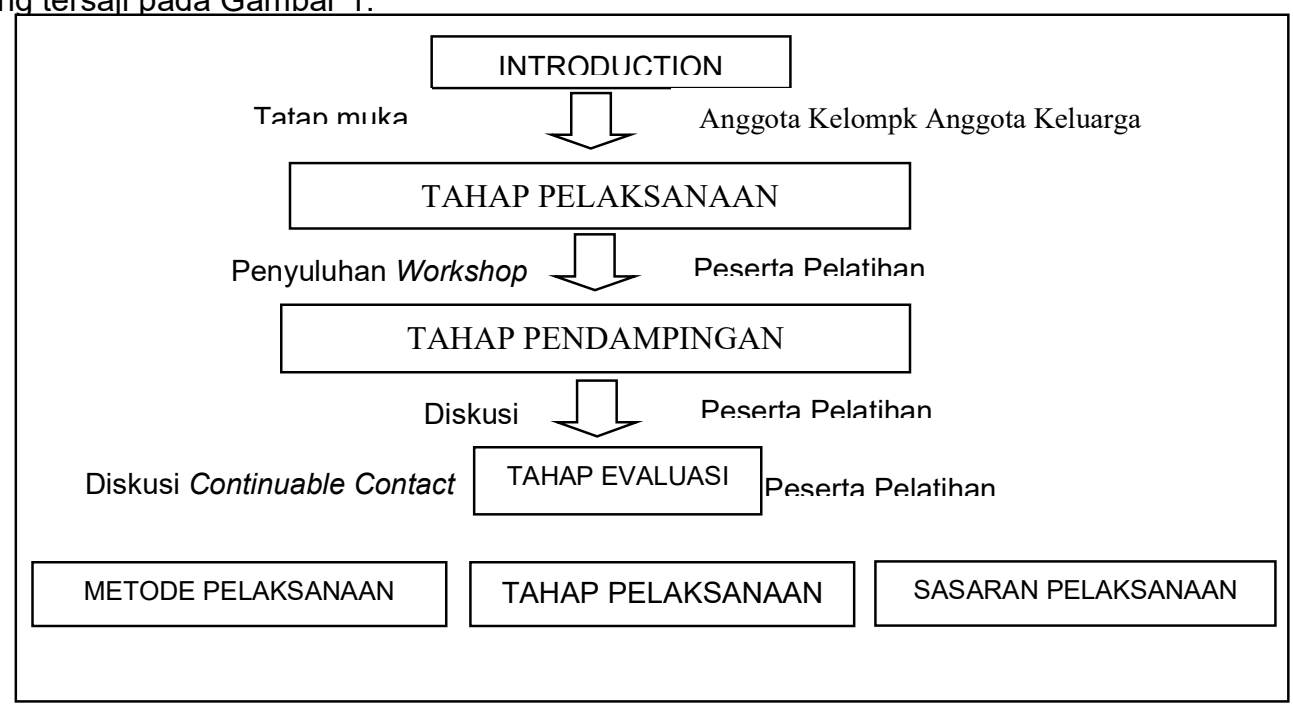




\section{HASIL DAN PEMBAHASAN}

Kegiatan pengabdian kepada masyarakat ini berlangsung interaktif dimana peserta antusias dalam mengikuti kegiatan dibuktikan dengan beberapa pertanyaan yang diajukan sehingga kondisi pelatihan terlihat hidup. Peserta memberikan atensi sejak pelatihan dimulai hingga proses produksi dan menghasilkan produk nugget dan mie ikan Nila. Hasil kegiatan Pengabdian kepada Masyarakat menunjukkan bahwa peserta dalam kegiatan Pengabdian kepada Masyarakat semua berjenis kelamin perempuan. Hal ini dimungkinkan karena topik dalam kegiatan ini adalah diversifikasi produk olahan berbahan baku ikan nila yang memiliki konotasi pekerjaan perempuan. Data dari ke dua desa, seluruh peserta yang memiliki rentang usia 17-45 tahun dengan persentase tertinggi pada rentang umur 26-35 tahun (Gambar 2.). mengalami ketidakberdayaan yang lebih tinggi bila dibandingkan dengan pekerja yang lebih tua. Hal ini dapat terjadi dikarenakan pekerja yang lebih muda cenderung rendah pengalaman kerjanya jika dibandingkan dengan pekerja yang lebih tua, ataupun disebabkan karena faktor lain seperti pekerja yang lebih tua cenderung lebih stabil, lebih matang, mempunyai pandangan yang lebih seimbang terhadap kehidupan sehingga tidak mudah mengalami tekanan sehingga produktivitas akan terjaga. Pendidikan dianggap sebagai sarana untuk menghasilkan sumberdaya manusia yang berkualitas yang mempunyai pola pikir dan cara bertindak yang dinamis. Tingkat pendidikan peserta pelatihan dapat dilihat pada Gambar 3.

Awal kegiatan penyuluhan dilakukan pengisian kuisioner untuk mengetahui tingkat pengetahuan peserta terhadap produk olahan berbahan baku ikan. Hal ini untuk mengukur

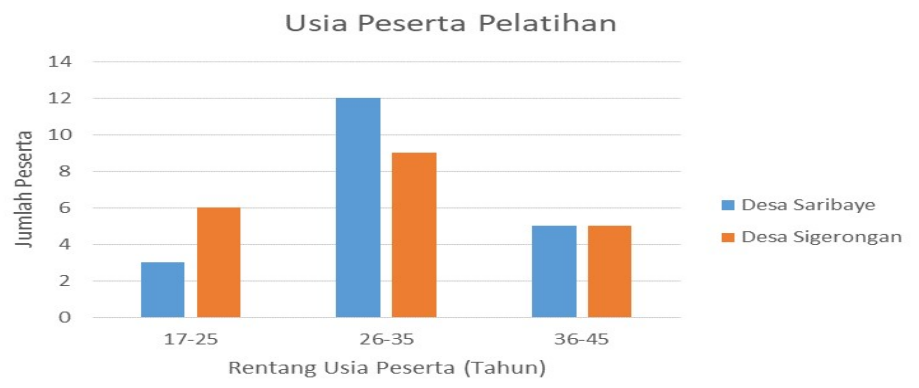

Gambar 2. Rentang Usia Peserta Pelatihan ketercapaian kegiatan Pengabdian kepada

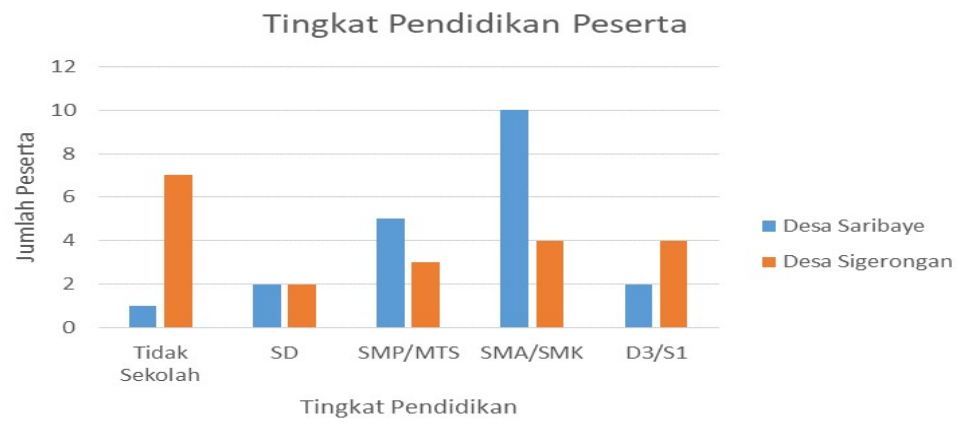

Gambar 3. Tingkat Pendidikan Peserta Penyuluhan

Dalam membuat produk olahan berbahan baku ikan nila, usia dan tingkat pendidikan responden atau peserta memberikan pengaruh terhadap produktivitas kerja. Usia berpengaruh terhadap emosional dan keberdayaan untuk menghasilkan suatu produk. Pekerja lebih muda cenderung
Masyarakat yang dilakukan. Pengisian kuisioner dilakukan secara terarah yaitu dengan membacakan pertanyaan dan peserta menuliskan jawaban sesuai dengan yang dialami yaitu dengan jawaban Ya dan Tidak. Pertanyaan yang diberikan dapat dilihat pada Tabel 1. Pengisian kuisioner dilakukan pada semua peserta penyuluhan baik dari Kelompok Pembudidaya Ikan Telaga Biru, Desa Sigerongan maupun 
Kelompok Pembudidaya Ikan Padegirang, Desa Saribaye.

Hasil jawaban peserta menunjukkan bahwa peserta dari kedua Kelompok Pembudidaya Ikan pernah mendengar produk olahan berbahan dasar ikan dan sebagian kecil pernah mengkonsumsi produk olahan berbahan dasar ikan. Hasil kuisioner juga menjelaskan bahwa mayoritas peserta belum pernah tahu produk olahan berbahan dasar ikan nila demikian juga untuk mengkonsumsinya. Untuk itu, dari hasil kuisioner diketahui pula bahwa peserta sangat antusias untuk belajar dan mengembangkan produk untuk dapat dipasarkan.

Hasil pengolahan data kuisioner menunjukkan bahwa kegiatan Pengabdian kepada Masyarakat yang dilakukan memang sesuai kebutuhan masyarakat setempat dan penentuan peserta pelatihan dan workshop telah sesuai dengan harapan masyarakat. Dengan hasil tersebut diharapkan tujuan akhir untuk meningkatkan pemberdayaan anggota kelompok pembudidaya ikan dapat tercapai karena sasaran antara dalam kegiatan tersebut telah tepat. Hasil Kuisioner sebelum dan sesudah penyuluhan dapat dilihat pada Gambar 4.

Gambar 4. Grafik Tingkat Pengetahuan dan Keinginan Mengikuti Penyuluhan Pengolahan Produk Olahan Berbahan Dasar Ikan Nila. A. Peserta kelompok Telaga Biru sebelum penyuluhan, B. Peserta kelompok Padegirang sebelum penyuluhan, C. Peserta kelompok Telaga Biru setelah penyuluhan dan $D$. Peserta kelompok Padegirang setelah penyuluhan
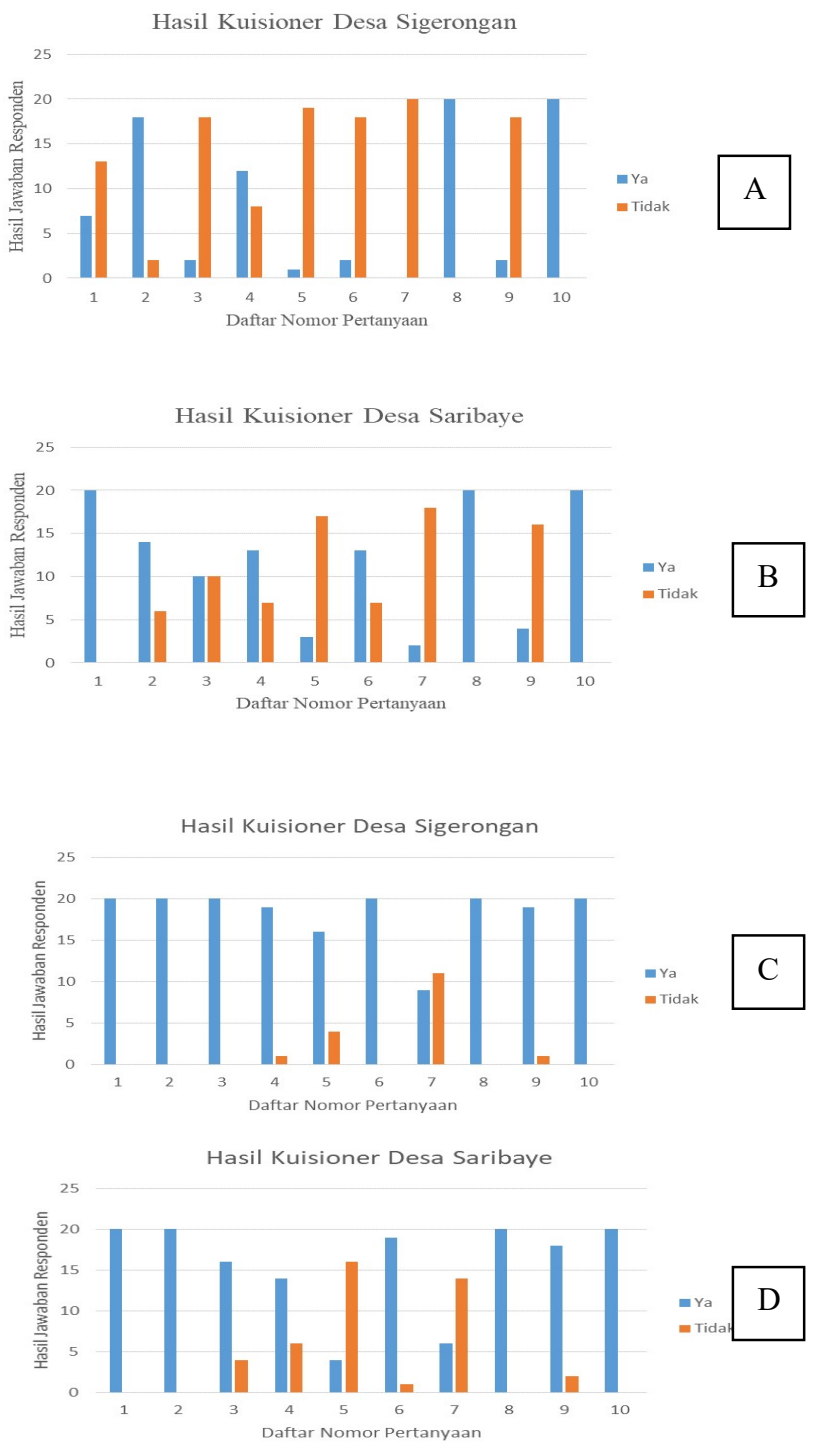
A. Kegiatan Pengabdian kepada Masyarakat yang telah dilakukan memberikan efek pemahaman dan keterampilan yang lebih meningkat terhadap berbagai produk olahan berbasis ikan jika dibandingkan dengan penyuluhan pada tahap pertama di bulan Juli. Hal ini dapat terlihat pada semakin banyaknya responden atau peserta yang sudah banyak menjawab setiap pertanyaan dengan jawaban "ya". Selain itu, dilakukan wawancara dimana keterampilan peserta lebih meningkat, mereka menceritakan bahwa dalam pembuatan nugget dan mie ikan Nila dilakukan tanpa melihat resep, sudah mampu mengingat tahapan dalam pembuatan nugget dan mie ikan Nila. Dengan hasil tersebut diharapkan tujuan akhir untuk meningkatkan pemberdayaan anggota kelompok pembudidaya ikan dapat tercapai karena masyarakat telah mampu memproduksi dan memahami produk olahan berbahan baku ikan nila.

Materi pengolahan produk olahan berbahan baku ikan nila sangat membantu masyarakat setempat khususnya keluarga pembudidaya ikan nila untuk melakukan diversifikasi produk dalam usahanya selama ini. Proses perlatihan dapat dilihat pada Gambar 5. Hasil pengolahan produk olahan berbahan baku ikan nila berupa nugget dan mie, selanjutnya diolah menjadi bahan olahan yang siap saji dengan dimasak sesuai dengan selera peserta workshop dapat dilihat pada Gambar 6.

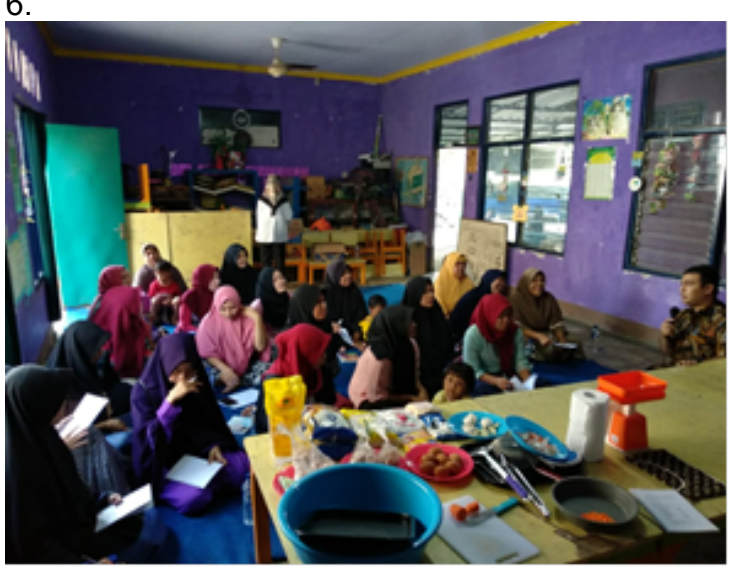

Gambar 6. Hasil Olahan Nugget dan Mie Ikan Nila
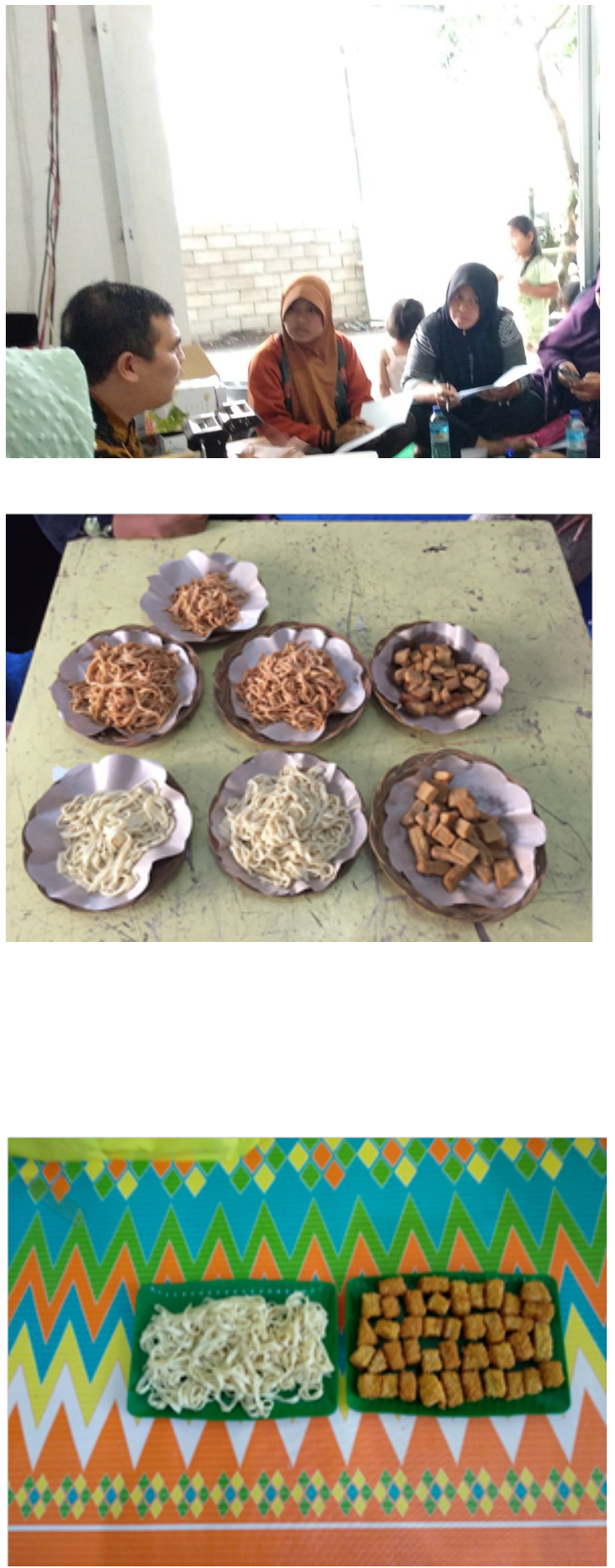


\begin{abstract}
B. Kenampakan merupakan visualisasi suatu produk langsung yang terlihat lebih dahulu dibandingkan parameter lainnya sehingga kenampakan akan mempengaruhi langsung terhadap persepsi panelis. Aroma atau bau merupakan salah satu parameter kunci dimana pada umumnya cita rasa konsumen terhadap produk makanan akan sangat ditentukan oleh bau. Di sisi lain, tekstur akan menghasilkan tanggapan yang sama seperti terhadap kenampakan. Hasil uji hedonik di Desa Sigerongan dan Saribaye dapat dilihat pada Gambar 7.
\end{abstract}

Berdasarkan hasil uji hedonik (tingkat kesukaan), produk nugget ikan nila dari Desa Sigerongan dan Saribaye sama-sama menunjukkan hasil yang baik. Nugget yang diproduksi di Desa Sigerongan menunjukkan bahwa panelis menyukai hasil nugget ikan nila dengan rata-rata nilai untuk kenampakan adalah 8 , bau dengan nilai 7 , rasa dengan nilai 8 dan tekstur dengan nilai 8 . Sedangkan di Desa Saribaye tidak kalah menunjukkan hasil yang sama baiknya yaitu kenampakan dengan nilai 7 , bau dengan nilai 8 , rasa dengan nilai 8 dan tekstur dengan nilai 7 . Hasil tersebut menunjukkan bahwa kedua Desa sudah mampu membuat olahan nugget ikan nila dan dapat dipasarkan untuk mengangkat perekonomian dari para anggota pembudidaya ikan baik Pade Girang maupun Telaga Biru.

Hasil Uji Hedonik Desa Sigerongan
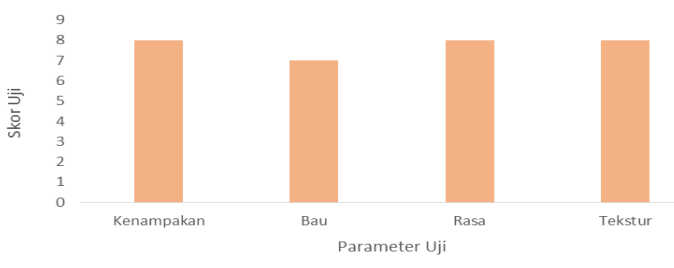

Hasil Uji Hedonik Desa Saribaye

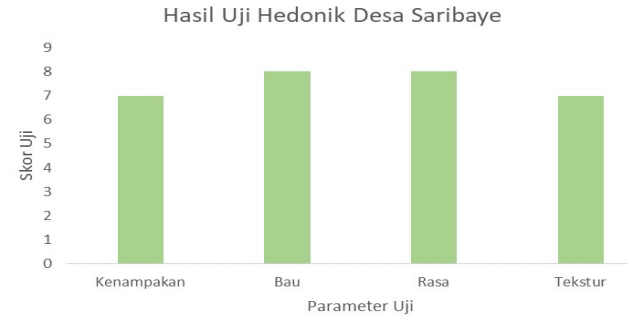

Gambar 7. Hasil uji hedonik. A. Desa Sigerongan dan B. Desa Saribaye

\section{KESIMPULAN}

a. Kelompok Mitra memiliki semangat dan motivasi tinggi untuk mengikuti pelatihan kegiatan Pengabdian pada masyarakat.

b. Kelompok Mitra memiliki keterampilan yang memadai untuk menghasilkan produk olahan dari bahan ikan Nila.

c. Kelompok Mitra telah berhasil memproduksi bahan baku ikan nila dan memilik motivasi untuk memproduksi produk olahan bahan baku ikan nila.

\section{SARAN}

a. Perlu pendampingan lebih lanjut untuk pengemasan produk berbahan dasar ikan nila.

b. Perlu dilakukan penyuluhan lebih lanjut tentang pengemasan dan analisis usaha dalam pemasaran produk berbahan dasar ikan nila

\section{DAFTAR PUSTAKA}

Dinas Kelautan dan Perikanan Lombok Barat.2016. Laporan Tahunan Dinas Kelautan dan Perikanan Lombok Barat. Dinas Kelautan dan Perikanan Lombok Barat. Nusa Tenggara Barat.

Febianti, Y.N. 2014.Permintaan dalam Ekonomi Mikro. Jurnal Edunomic: 2(1)

Kementerian Kelautan dan Perikanan. 2015. Data Statistik Kementerian Kelautan dan Perikanan. Kementerian Kelautan dan Perikanan Indonesia. Jakarta.

Laksono, A.G., M. Ipa, I. Kusrini, A. Sudrajat. 2015. Geliat Sistemik Kabupaten Lombok Barat. Kanisius. Jakarta

Lombokbaratkab.go.id. 2018. Pemerintah Kabupaten Lombok Barat. http://lombokbaratkab.go.id. Akses: $10 / 02 / 2018$

Rifianto, I. 2000. Pengantar Produksi dan Tata Niaga Perikanan. Modul 1. Universitas Terbuka. Jakarta

Rika, N.P., A.Usman, S. Maryati. 2017. Analisis Rantai Nilai Pemasaran Ikan Air Tawar di Kabupaten Lombok Barat. Program Studi Agribisnis Fakultas Pertanian Universitas Mataram. Mataram

Sahwan F. 2004. Pakan Ikan Ekonomi dan Udang: Formulasi, Pembuatan, Analisa Ekonomi. Penebar Swadaya. Jakarta 
Juni Triastuti, dkk., Diversifikasi Pengolahan Ikan Nila....

Suparmin, N. Kusrini, E. Dolorosa. 2013 Analisis Distribusi Pemasaran Ikan Air Tawar Hasil Usaha Budidaya Keramba Jaring Apung (KJA) di Kota Pontianak. Jurnal Eksos. Th. IX. 6 (2) 